\title{
Digital Technology on Millenial Generation : Potere Mobile Devices on Primary Students for Supporting Learning
}

\author{
Ahmad Saiful Mirza ${ }^{1}$, Farid Ahmadi ${ }^{2}$, Lysa Amorita Rachmawati ${ }^{3}$, \\ Nashihah Laila Masruroh ${ }^{4}$ \\ ${ }^{1,2,3,4}$ Graduate School, Universitas Negeri Semarang, Semarang, Indonesia \\ Corresponding email: ahmir2okto91@students.unnes.ac.id
}

\begin{abstract}
The revolution of digital technology has major change on lifestyle, economics, entertainment, and education. In education sector, digital technology assists learners to learn something new rapidly. This paper purposes to potere digital technology in the form of mobile learning for primary students. This reasearch took primary students in one of the sub-urban schools in Semarang as the participants. This paper showed that millenials, in this case primary students, used gadget on any circumstance. They used their gadgets (smartphone and tablets) in learning and entertainment purposes. The students learned sciences, technology, and mathematics through mobile games, youtube, and social media. It indicates acceleration to upgrade human skills and knowledge.
\end{abstract}

Key words: technology, learning, students

\section{Introduction}

The Industrial Revolution 4.0 has a tremendous impact on the current time. The changes have tremendous influence in various fields such as industry, economics, social, and culture. Besides, industrial revolution also has an impact on education in schools (Benešová \& Tupa, 2017). It is also supported by the $21 \mathrm{st}$ century skills, especially the skills of information and communication technology (ICT) (Chu, Reynolds, Tavares, Notari, \& Lee, 2017). The students are required to master that kind of skill.

The acquisition of 21 st century skills can be done through learning in school. 21st century skills consist of critical thinking, communication, collaboration, and creativity (Patnership for 21st Century Learning, 2016). The skills that can be cultivated through information technology is the one related to the field of communication. It is implemented in learning by using the applications of mobile learning. Mobile learning can be defined as one type of learning where mobile devices such as smartphones or tablets can be used as a tool for learning (Baek \& Zhang, 2017). Android-based smartphones can be used in the implementation of mobile learning. Mobile learning is a stage in the development of electronic learning (Rekkedal, Dye, \& Fagerberg, 2005).

Primary school students in their cognitive development has a operational concrete stage (Bakir \& Bİçer, 2015). This stage on children is only consist of being able to think concretely. Learning requires media that can help to transfer concrete knowledge into children's mind. One of the most massive media to be used in transferring children's knowledge is mobile devices such as smartphone or tablet based on either android or IOS. Mobile learning features comprises augmented reality, video, and virtual reality. Augmented reality is a 3D technology that can increase the perception of user's sensory in the real world with contextual information (Ibáñez \& Delgado-kloos, 2018). In such cases, learners can receive real information through the device. Augmented reality technology can provide students' insights in various disciplines quickly and clearly (Salmi, Fairuz, Wai, \& Oskam, 2015) . It is also able to access the anatomical fields of animals, plants, and also the shape of the earth quickly and real. Likewise, virtual reality can provide a real video to learners. Learning by using virtual reality can foster new skills such as language acquisition, sharing, visual data visualization (Shin, 2017).

Technological development, especially gadgets, is expected to give good impacts in learning activities. On the contrary, information technology is a mobile device in the form of smartphone and tablet that can support in helping the learning process. Thus, this paper will illustrate the portrait from respondents, in this case primary students, conducted in the suburban area in Semarang in terms of 1) the ability to use mobile devices 2) the intensity of the use of mobile devices, and 3) the learners' desire in utilizing the mobile device for learning. 


\section{Methods}

This paper is survey research conducted in a primary school. This paper portrays the use of mobile devices on primary school students to support learning. The participants of this study were $4^{\text {th }}$ grade primary school students in a suburban area in Semarang. There were 44 students (with average age of 115 months). There were equal number of girls. All participants had smartphone.

\section{Results and Discussion}

This section provides three sets of analysis about the use of mobile device on Primary school students to support learning. They are the ability to use mobile devices, the intensity of using mobile devices, and the learners' desire in utilizing mobile device for learning.

a. Ability of using mobile devices

All students ever used a smartphone. While most students used android-based device, only 10 students used iOS-based device from Apple. The rest used devices from other than android and IOS (Blackberry and windows).

Programs or applications that were operationalized by students are games, chats, video streaming, social media, browsers, and music. 36 elementary students used game as. Besides, 30 elementary school students used chat applications, and 40 elementary school students operated streaming video. In addition, 27 students used social media applications, and 23 students operated the browser program. As many as 30 students used music program.

\section{b. Intensity of Using Mobile Devices}

In terms of the intensity of using mobile device 14 student claimed they used mobile device less than half hour per day, and 16 primary school students stated they spent half an hour to two hours per day. Meanwhile, 24 students used mobile devices more than 2 hours per day.

The program often used by learners is game. 30 students frequently used the game on their mobile device while 5 students chose to frequently use chat apps in their devices. Youtube video streaming was selected by 10 students in terms of the application they frequently used. Only 4 students who frequently used social media.

\section{c. Learners' Desire in Utilizing Mobile Device for Learning}

Surveys conducted by researchers on technology specialization in supporting learning tools indicated that the game content was the most widely chosen applications by students. 38 students chose game content to serve as a means of student learning. Moreover, 27 students chose the means of chatting to support learning. Almost all respondents (41 students) chose video application to support learning process. 25 students chose social media that can be used as a means of learning. Then, 20 respondents chose browser applications to support learning. The digital book is selected by 32 students, and office applications such as microsoft word or excel are selected by 18 students.

Research subjects found that all students or respondents were able to operate a smartphone. Such ability can also be used in learning activities. It is supported that the presence of mobile technology also greatly influences the improvement of mobile technology in education (Miguel et al., 2018). In addition, it is also supported that the use of mobile technology in learning has been implemented in 2007 (Frohberg, Göth, \& Schwabe, 2009). Thus, the carrying capacity to develop or support the achievement of learning that utilizes the technology in the area for the present time can be accomplished. In addition, learning with mobile devices can have a good impact on learners in the mastery of 21 st century skills (Mcquiggan, 2015).

The result showed the most widely used applications or programs was games and video streaming. Kind of game preferred by the respondents was adventure-themed game. Game-based learning by using mobile devices provides benefits with increased focus on selflearning (Romero, Usart, \& Ott, 2015). While video streaming application used for learning was Youtube. Youtube platform also provides a lot of educational-themed contents.

The use of mobile devices in primary school children against the survey in this paper proves that most respondents use it for more than two hours per day. This is a change due to the industrial revolution 4.0 that the real world can already be represented against the world of diigital (Fathur Rokhman, 2017). It can not be denied also that human activity has also shifted in various fields such as communication, shopping, or entertainment.

The survey showed that elementary school children wanted to change the learning media with mobile devices or known mobile learning. Mobile devices are now a very flexible device. This is demonstrated by the full range of 
available mobile device facilities such as camera, internet, video, game, and so on. The use of mobile devices also integrates all aspects of life in all countries (Al-hunaiyyan, Alhajri, \& Al-sharhan, 2018). Therefore, the ease provided will be very good to enhance to help learning, especially with the fact that internet access used for learning is also getting easier.

\section{Conclusion}

Survey aimed at suburban area of semarang in elementary school children in fulfillment of mobile device in supporting learning show a good thing. With the background of students who are able to master mobile devices well, the available facilities as well as the development of mobile device program can be achieved. Based on the survey conducted on elementary-school children, they mostly chose the theme of games and video contents as a means of learning.

\section{References}

Ahmadi, F. (2017). Guru SD Era Digital: Pendekatan, Media, Inovasi. Semarang: Pilar Nusantara.

Al-hunaiyyan, A., Alhajri, R. A., \& Al-sharhan, S. (2018). Perceptions and challenges of mobile learning in Kuwait. 279-289.

Baek, Y., \& Zhang, H. (2017). Teachers' Attitudes toward Mobile Learning in Korea. The Turkish Online Journal of Educational Technology, 16(1), 154-163.

Bakir, S., \& Bİçer, E. Ö. (2015). Logical Thinking and Cognitive Development Levels of Pre-service Science Teachers. Juornal of Educational Sciences Research, $5(1)$, 149-163. https://doi.org/http://dx.doi.org/10.12973/j esr. 2015.51.9 1

Benešová, A., \& Tupa, J. (2017). Requirements for Education and Qualification of People in Industry 4.0. Procedia Manufacturing, 11(June), 2195-2202. https://doi.org/10.1016/j.promfg.2017.07.3 66

Chu, S. K. W., Reynolds, R. B., Tavares, N. J., Notari, M., \& Lee, C. W. Y. (2017). 21st Century Skills Development Through Inquiry-Based Learning. https://doi.org/10.1007/978-981-10-2481-8
Fathur Rokhman. (2017). International Conference on Language, Literature, and Teaching. In Peningkatan Kecakapan sumber Daya Manusia Pada Revolusi Industri 4.0 dengan Literasi (pp. 5-17). Semarang: Jurusan Bahasa dan Sastra Indonesia Fakultas Bahasa dan Seni Universitas Negeri Semarang.

Frohberg, D., Göth, C., \& Schwabe, G. (2009). Mobile Learning projects - a critical analysis of the state of the art, 307-331. https://doi.org/10.1111/j.13652729.2009.00315.x

Hao, S., Dennen, V. P., \& Mei, L. (2017). Influential factors for mobile learning acceptance among Chinese users. Educational Technology Research and Development, 65(1), 101-123. https://doi.org/10.1007/s11423-016-9465-2

Ibáñez, M., \& Delgado-kloos, C. (2018). AC SC. Computers \& Education. https://doi.org/10.1016/j.compedu.2018.05. 002

Imtinan, U., Chang, V., \& Issa, T. (2013). Common mobile learning characteristicsan analysis of mobile learning models and frameworks. Proceedings of the IADIS International Conference Mobile Learning 2013, ML 2013, 3-11.

Jaldemark, J. (2013). Context and concepts in mobile learning. Mobile Learning 2013 :, (1987), 230-234.

Mcquiggan, S. (2015). Mobile Learning: A Handbook for Developers, Educators, and Learners (pp. 325-340). John Wiley \& Sons, Inc.

Miarso, Y. (2007). Menyemai Benih Teknologi Pendidikan. Computer. Jakarta: Prenada Media. https://doi.org/10.1038/cddis.2011.1

Miguel, I. De, Lorenzo, R. M., Ruíz, I., Debrán, J., Aguado, J. C., Durán, R. J., ... Abril, E. J. (2018). AIM-Mobile Learning Platform to enhance the teaching-learning process using smartphones, (April). https://doi.org/10.1002/cae.21979

Ng, W., \& Nicholas, H. (2013). A framework for sustainable mobile learning in schools. British Journal of Educational Technology, 
44(5),

https://doi.org/10.1111/j.1467-

8535.2012.01359.x

Patnership for 21st Century Learning. (2016). Framework for 21st Century Learning. The Partnership for 21st Century Learning, $37(4)$,

589. https://doi.org/10.2307/3588214

Rekkedal, T., Dye, A., \& Fagerberg, T. (2005). Design, development and evaluation of mobile learning at NKI distance education 2000-2005. Leonardo Da Vinci EU ..., (September 2005). Retrieved from http://dye.no/articles/mlearning/m_Learnin g_2000_2005.pdf

Romero, M., Usart, M., \& Ott, M. (2015). Can Serious Games Contribute to Developing and Sustaining 21 st Century Skills? Games and Culture, 10(2), 148-177. https://doi.org/10.1177/155541201454891
9

Salmi, S., Fairuz, M., Wai, K., \& Oskam, C. L. (2015). Utilising Mobile-Augmented Reality for Learning Human Anatomy. Procedia - Social and Behavioral Sciences, 197(February), 659-668. https://doi.org/10.1016/j.sbspro.2015.07.05 4

Sayodih, N. S. S. \& E. (2012). Kurikulum dan Pembelajaran Komptensi. Bandung: Bumi Aksara.

Shin, D. (2017). The Role of Affordance in the Experience of Virtual Reality Learning: Technological and Affective Affordances in Virtual Reality. Telematics and Informatics. https://doi.org/10.1016/j.tele.2017.05.013

Syatori, A. A., \& Odi Susanto. (2017). Strategi Pembelajaran Efektif, (May), 201. 